\title{
Science teacher education in Taiwan: past, present, and future
}

\author{
Hsiao-Lin Tuan ${ }^{1 *}$ and Yu-Ling Lu ${ }^{2}$
}

\author{
* Correspondence: suhltuan@cc. \\ ncue.edu.tw \\ ${ }^{1}$ Graduate Institute of Science \\ Education, National Changhua \\ University of Education, Changhua \\ City, Taiwan \\ Full list of author information is \\ available at the end of the article
}

\begin{abstract}
For the purpose of introducing the trends and development of science teacher education in Taiwan, three stages of teacher education were explored in this study: the distant past (DP): 1949 to 1994; the immediate past (IP):1994 to 2017; and the present and future (PF): 2018 and beyond. Each of the three stages has had a different emphasis on science teacher education. In the DP stage, science teacher education in Taiwan focused mainly on preparing elementary and secondary school science teachers with sufficient science knowledge, pedagogical content knowledge and to be good role models in the classroom. During the IP stage, the "Teacher Education Act" [TEA] was enacted in 1994, and the teacher education system in Taiwan changed from a centralized system to a decentralized one. Multiple channels were opened for teacher preparation. In this period of time, the purpose of science teacher education shifted from providing good role models and sufficient science knowledge to developing competency-based professional science teachers. All teacher education programs in Taiwan could offer science teacher education training courses for pre-service science teachers. In addition, the teaching internship duration was reduced from 1 year to one semester. Teacher certification became a dominant focus in each county or school. During the PF stage, an amended TEA was implemented in 2017, and 12-year continued curriculum standards were officially implemented in the public school system in 2019. The 12-year continued curriculum standards address inquiry, practices and cross-discipline instruction. Science teachers need not only to teach science content knowledge, but also to integrate content knowledge, inquiry competence and other discipline areas into their teaching. The demand for good science teachers is increasing. Meanwhile, the low recruitment rate for science teachers impedes the public's willingness to enroll in teacher education programs. Few teachers with bachelor degrees can pass the teacher certification exam necessary to be hired in teaching positions. Although the conditions for preservice science teachers are harsh, there is demand in our teacher education system to recruit science teachers with talent and passion.
\end{abstract}

Keywords: Elementary science, History of education, Science teachers, Secondary science, Taiwan, Teacher education

\section{摘要}

本篇論文主要介紹台灣科學教師教育在過去七十年的發展趨勢，依據過去的歷 史，我們大至將台灣的科學教師教育分為三個階段: 早期的階段 (1949-1994)，晚近 的階段(1994-2017)以及2017之後的階段。在每一個階段科學教師教育的重點有 (Continued on next page) 
(Continued from previous page)

些不同。在早期的階段，台灣的科學教師教育主要目標在培養國小與中學科學教

師具備充分的學科知識，學科教學知識，以及在教室中扮演好的楷模。在晚近的

階段，自從師資培育法於1994年通過後，台灣的教師教育系統由集中培養制度改

為分散培食制度。培養科學教師的管道由集中式培食改為可由多種管道培

育。在此階段，科學教師教育由培養教師成為好的楷模以及充分的學科知識，轉 為培養科學教師具備以能力為主的專業科學教師。全台灣只要有師培中心的大 學均能培食職前科學教師。除此之外，此階段的另一變革是教學實習由一年縮短 為一個學期。教師認証成為各縣市教育局處或是學校的責任。自2017之後的階 段,則受到2017師資培育法修改，以及2019年十二年國民基本教育課程綱要實施 的影響，崖生變化。新的課程標準強調探究，實作以及跨領域的課程教學。在此 階段，科學教師不僅只要教學科知識，他們也必須統整科學知識，探究能力以及其 他學科領域的內容於其教學中。社會上對於好的科學老師的標準越來越多。在 此同時低的教甄錄取率使得大學生越來越不願意進入師培課程。此外，僅有非常 少數的學士級畢業生可通過教檢與教甄成為學校任教的合格老師。雖然在此階 段，職前科學教師所面臨的挑戰非常艱困，但是我們仍需要招募優秀且具備熱情 的教師進入科學教師教育系統。

關鍵詞: 國小科學，教育史，科學教師，中學科學，台灣，教師教育

\section{Introduction}

Taiwan is an island geographically situated in East Asia. Neighbors include mainland China, Japan and the Philippines. Taiwan was first set upon by Portuguese sailors and Spanish settlers in the sixteenth century and these settlers originally called the island "Formosa (the beauty island)". The government of the Manchu Dynasty ceded the island to Japan as part of the 1895 Treaty of Shimonoseki. According to this treaty, Taiwan was to remain under Japanese colonial rule for 50 years. However, in 1945, after Allied forces at the end of World War II defeated Japan, Taiwan returned to being the Republic of China (ROC) (Ministry of Foreign Affairs 2019).

Today, the total area of Taiwan and related islands is around thirty-six thousand square kilometers with a population of around 23 million. The official language is Mandarin. Taiwan's export-oriented industrial economy is the 21st-largest in the world, ranking 15th in GDP per capita and Taiwan in well known as science and technology island (Wikipedia 2019). Due to the high density of population, lack of natural resources, and influence of the Chinese culture, people in Taiwan tend to value education and Confucianism very much. This is because it is believed that education can improve one's economic position in society and can also promote Taiwan's economic development. There is a saying “萬般皆下品唯有讀書高” (Nothing is more important than learning), which indicates the main goal of education is to cultivate an individual's character, which can help to improve the individual's social status and economic situation. This saying reveals how much Taiwanese people value education.

Taiwan's science teacher education embraces the east and west as well as both the tradition and modern. Nowadays, due to the efforts of science teachers and educators, the achievement of elementary and secondary students frequently ranks near the top in international comparative science assessments (Mullis et al. 2016). In 2015, Taiwanese students' achievement was fourth best in mathematics and science on the Programme for International Student Assessment (PISA). In addition, Taiwan's publications in top science education journals have also been ranked number one in Asia and among the 
top-ranked at the international level (Lin et al. 2019). In addition to this, studies have shown that teachers in Taiwan have the highest percentage of graduate degrees among most countries in East Asia (Otsuji et al. 2016).

During the past 70 years, historical events and policy changes have strongly influenced education and science teacher education in Taiwan. We believe providing readers a historical perspective with informed reflection will help reveal the process of developing science teacher education as well as teacher education in general. In addition, it can help provide insights about how to develop better policies and actions for future science teacher education in Taiwan, and perhaps offer insights for other educational systems as well. Thus, in this paper, we will describe the development of the Taiwanese Education system during the past 70 years by focusing on three sections: the distant past stage (DPs; 1945-1993), the immediate past stage (IPs; 1994-2017); and the present and future stages (PFs: 2018 and beyond). For each section, we introduce historical events, which mainly influenced the science teacher education programs in Taiwan, and we build from this discussion to describe the need for continued and future developments in science education and science teacher preparation specifically.

Many educational studies have pointed out that teachers are an important factor influencing students' success (Darling-Hammond 2000; Druva and Anderson 1983; Lu and Lien 2009; Rivkin et al. 2005; Rockoff 2004). The better teachers are prepared, the better their teaching effectiveness. Therefore, science teachers decisively affect the success of science education and have an impact on the scientific and technological developments of a society. As a consequence, the quality of science teachers is vital to the country's technological advancement and economic development. Thus, the cultivation of science teachers is an important topic for constructing a better society.

With consideration for social, political, and educational contexts, as well as trends in science teacher education development in Taiwan, this paper attempts to answer the following research questions:

1. How has the external social and political factors (i.e., the rationale of education, educational system, the perception of science teachers) impacted teacher education in Taiwan?

2. What are the characteristics of the educational system and curriculum of Taiwan's science teacher education in the past and present, and what are the implications for the future?

3. What changes have occurred in Taiwan's science teacher and career development in the past and present, and what are their implications for the future?

\section{The distant past: 1945 to 1993}

In 1945, Taiwan returned to the jurisdiction of the Republic of China's (ROC) government after 50 years of Japanese colonialism. Shortly after, in 1949, the ROC government relocated from mainland China to Taiwan where the ROC has governed until now. In 1946 there were only 6 years of compulsory education. In 1968 compulsory education was extended from grade 6 to grade 9. In 2014 the compulsory education system was expanded from grades 1-12. Thus, the current Taiwan education system consists of 6 years of elementary school, 3 years of junior high school and 3 years of senior high (or 
vocational) school. Post-secondary education includes 4 years of university. In 2018 there were 2631 elementary schools, 737 junior high schools, 153 senior high and vocational schools, and 153 universities and colleges in Taiwan (MOE 2018).

To enable readers to have a better understanding of the whole spectrum of the development of education and science teacher education in this period, the main historical events are shown in Fig. 1.

In this figure of historical landmarks, we have positioned major social or political changes above the timeline and have positioned transitions of laws and changes in national educational regulations and to the education system below the time line. In the following sections, we describe the historical development of normal school and universities in relation to the development of general processes for selecting and preparing pre-service secondary and elementary teachers.

\section{Development of normal universities and teacher education programs}

Teacher preparation from 1949 to 1993 was based on the Normal School Act (Ministry of Education [MOE] 1932) and the Amendment Normal School Regulations (MOE 1947). In this period, normal universities, teachers colleges and junior colleges, and teachers schools carried out the cultivation of teachers. Namely only institutes established by the central government could cultivate in-service teachers. Moreover, the elementary and secondary teachers were prepared in normal universities or teachers colleges. The government estimated the number of teachers needed in different discipline areas at different educational levels before teacher preparation institutes recruited their candidates so there was no excess in the number of teachers prepared for employment. All pre-service teachers were provided with free tuition and living costs. After they graduated, the government arranged for them to each have a teaching job in a public school.

During this time period, there were dramatically increased numbers of public junior and senior high schools established to cultivate citizens' literacy levels. For example, in 1915, there were only 3 high schools. In order to prepare new teachers to meet the increased teaching demand for junior high schools after World War II, the Taiwan

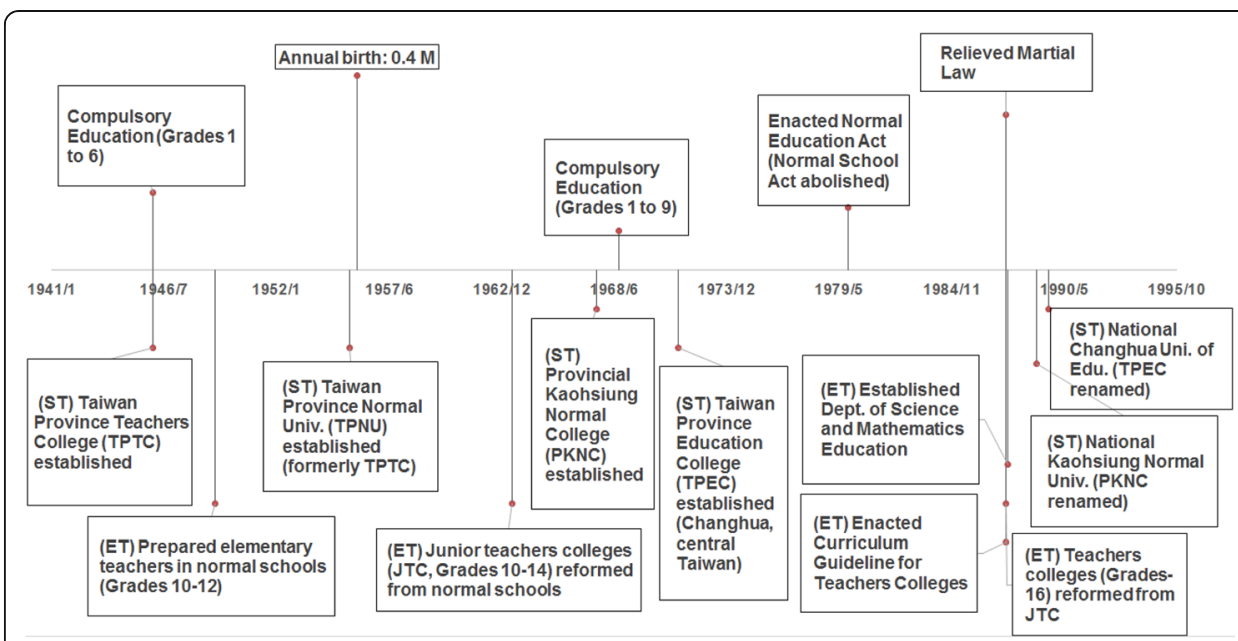

Fig. 1 The historical landmarks during the distance past stage (DPS): 1945-1993 (ST: secondary teacher; ET: elementary teacher) 
Provincial Teacher's College was established in Taipei city in 1946. At this time, both a physical science and general science departments were established to prepare high school science teachers. By 1950 there were 66 high schools and in 1955, Taiwan Province Teacher's College changed the name to Taiwan Provincial Normal University. The main aim of Taiwan Provincial Normal University was to prepare secondary school teachers (junior and senior high school teachers).

In 1962, the Taiwanese government intended to enhance elementary school teachers' competency by extending the three-year normal school to a 5-year junior teachers' college program (Grades 10-14) that required a one-year internship teaching in a local school. In 1963, prospective teachers were selected from high school graduates (grade 9) who had passed a competitive exam to attend a three-year government-supported normal school (grades 10-12). The Taiwan Provincial Normal University changed its name again to National Taiwan Normal University [NTNU] in 1967. NTNU continues to be a leader in educational research and teacher preparation in Taiwan today.

In 1968, the government led by Chiang Kai-Shek implemented a nine-year compulsory education requirement that meant all children from ages 6 to 15 must attend public schools. In order to match the demand for qualified secondary school teachers, two other normal universities were subsequently established: one in southern Taiwan and the other in central Taiwan. Due to the nine-year compulsory education policy in 1968, the government needs more qualified secondary school teachers, therefore Kaohsiung Girls' Teacher School, which mainly prepared elementary school teachers was changed the name as Provincial Kaohsiung Teachers' College and started to prepare high school teachers. The Provincial Kaohsiung Teachers' College established both chemistry department and physics department in 1978 to prepare high school chemistry and physics teachers. In 1989 Provincial Kaohsiung Teachers' College was renamed as the National Kaohsiung Normal University [NKNU].

In central Taiwan an in-service high school teacher training center known as the Taiwan Provincial Education College was established in 1971. At this time, a science education department was established which included a mathematics group. Physics and biology teacher groups were established in 1972, and a chemistry teacher group was established in the science education department in 1973. By 1981, the four teacher groups were renamed as mathematics, chemistry, physics, and biology departments. This college was renamed as the National Changhua University of Education [NCUE] in 1989.

By 1987, the government had required all junior teachers' colleges to be reorganized into teachers' colleges with four different departments, including science and mathematics education, social science education, language education, and with elementary education programs to help prepare teachers to have a subject specialty. Other departments focused on preparing teachers who majored in arts, music, sports, early childhood education, and special education.

By 1989, three national Normal Universities tasked with the major responsibility of educating all future secondary school science teachers had been established. The ROC government promoted science teacher preparation by transitioning preparation programs from high school level, to college and university levels and there by developing separate individual science discipline areas of physics, biology chemistry, and earth science from a general science area. The goal of these three Normal Universities was mainly to prepare qualified high school teachers with strong subject matter knowledge. 
Science teachers graduated from these universities with a Bachelor in science degree and after graduation, students could apply for positions as senior high school science teachers. The government provided financial support to all students enrolled in NTNU, NKNU, and NCUE. By 1993, there were 699 junior high schools and 90 senior high schools. Those supported by the government had an obligation to teach in junior (or senior) high school for at least 5 years. Finally, in 2005, all teachers' colleges were reorganized into universities for education that included departments of science education.

\section{Pre-service secondary science teacher selection and preparation}

Recruitment of pre-service secondary teachers was based on students' performance on a high stake entrance exam for university. Students needed to take exams in the areas of Chinese, English, Mathematics, Chemistry, and Physics or Biology, and an exam to test traditional Confucian knowledge. Based on their entire score and students' willingness to enroll in specific universities, students were assigned to certain universities and departments. Only about $30 \%$ of all students seeking admission to university were accepted. Admission to any of these three normal universities and their science-related departments was only possible the top 10\% of all senior high school graduates. Students enrolled in teacher colleges or normal universities were all called pre-service teachers and all pre-service science graduates from normal universities needed to take at least 154 credit hours total, which included at least 26 credit hours more than science major students in regular universities.

However, requirements for what courses were taken and how many credits per course varied depending on the university and major. For example, an NTNU biology major, in addition to biology coursework, needed to take 24 additional credit hours in courses like, Introduction of Education, Secondary Education, Educational Psychology, Teaching Principles, Education Media, Educational Testing and Measurement, Education and Vocational Counseling, Science Education, Teaching Materials and Methods, and Teaching Practice. However, for NKNU chemistry major, students needed to take more credit hours in teaching practice and in laboratory teaching. At all universities, most of these courses were offered by professors from education departments and only courses focused on science teaching materials and methods and teaching practicum were offered by different faculty in science departments.

Professors in different science department (physics, chemistry, biology) helped pre-service science teachers to be familiar with junior high school science curriculum and teaching methods. Pre-service science teachers had to practice teaching in front of their peers in the first semester and in junior high school classes for 1 month in the second semester. After studying in a science department for 4 years and following a teaching internship in a secondary (mainly junior high, 6 credit hours) school for 1 year, all pre-service science teachers were considered to be well prepared with strong subject matter knowledge and pedagogical content knowledge.

\section{Pre-service elementary science teacher selection and preparation}

As mentioned earlier, elementary and secondary teachers were prepared in different institutes. However, except for the curriculum students took, elementary and secondary teacher education was governed by similar regulations. Prior to 1963, elementary school teachers were prepared by normal schools. Historically, the first elementary pre-service programs required prospective teachers to take general science, chemistry, and physics for only $3 \mathrm{~h}$ per week per course. In total, science courses accounted for less than $9 \%$ of 
all coursework. Gradually, starting in 1955, science required coursework began to increase, but still accounted for only about $11 \%$ of all courses (Hung 2018, pp. 96-99). By 1978, pre-service teachers had to take $4 \mathrm{~h}$ each of biology, chemistry and physics per week for 1 year. In addition to these courses, an additional 2 credit hour course of science teaching was also required.

In the late 1980s, new regulations required that pre-service elementary teachers select a major subject from among several disciplines, including natural science, mathematics, social sciences, and language. Pre-service teachers who majored in sciences needed to take 30 credit hours of science coursework (Department of Education, Taiwan Provincial Government 1987a, 1987b, p. 115). The curriculum in this period was revised from an earlier curriculum framework (MOE 1987) and increased the course requirements for preservice elementary teacher education programs to be at least 140 credits, including: general education courses (70 credits), academic subject education (38 credits), and educational professional courses (40 credits)(MOE, 1993). Under this curriculum framework, non-science education major students would take sciences in the general education courses and science teaching method courses in the educational professional courses. Science major students were required to take an additional 38 credit hours in the sciences.

As a result of these many changes, elementary school teachers involved in science teaching had a considerable degree of scientific training and coursework in science teaching methods. An assessment of elementary science teachers' knowledge and teaching attitudes during this period (Lee 1992) found that the vast majority (90\%) of preservice teachers regarded natural science as important in elementary school, but a majority of general education teachers were afraid to teach science. General education teachers reported that their science knowledge was not enough to cope with the science teaching needs at the elementary level and this study found that pre-service teachers felt they had insufficient higher-level thinking skills. However, this study found that the more science courses a pre-service teacher had taken, the more positive their science teaching attitudes were. Thus, prospective teachers who majored in science and who had a considerable degree of scientific expertise could play important roles supporting science teaching and learning in elementary schools. It is important to note that even though pre-service teachers could have a science focus, their teaching certification was only as a general elementary educator. This means that in elementary schools, generally speaking, all teachers - even those with different subject specialties could and were expected to teach science courses.

\section{Unique features of teacher preparation programs 1945-1993}

Because members of Taiwanese society valued education so much, securing a teaching position was perceived as being a highly coveted position that would guarantee a high social status in society. In addition, many of the parents expected their daughters to attend Normal Universities because "teaching" was a good job to maintain their future family and well social being. In this period of time, many students from less wealthy families chose Normal universities as their first aspiration, so these three normal universities were able to select from top students and could prepare highly qualified teachers with strong science subject matter knowledge to serve society. These factors allowed Normal Universities to be able to recruit high quality students into teacher 
preparation programs (Fwu 1995; Liang and McClain 1991; Lin 1983; Wang and Huang 2016). However, due to the education laws at the time, teacher preparation programs lacked consistency in program requirements (Cheng 2006).

Although there was some variation among the teacher preparation programs in Taiwan at that time, they all shared some unique qualities. For example, there was intense competition to enter one of the three Normal Universities because the government offered free tuition, free lodging, and were guaranteed teaching positions and competitive salaries after graduation. After finishing four-years of coursework, pre-service teachers were ranked by GPAs to determine in which schools and in which counties the teachers would be best suited to serve. The Department of Education in each county was in charge of distributing all the prospective teachers into different junior high schools based on GPA and the willingness of the teacher to accept their assignment. Once prospective teachers enrolled in a high school, they automatically became intern teachers in the schools. Intern teachers had the same benefits as regular teachers. After a one-year internship, they would receive a final score from the university. At that time they were considered to have officially graduated from the normal university and they could continue serving in the same schools where they had served as interns. As long as the prospective teacher did not break any school regulations, they could easily pass the internship requirements to become hired full time and no formal examination was required.

Additionally, until 1991, the ROC government ruled Taiwan under Martial Law so preparing patriotic teachers was considered to be very important. To support the development of patriotic teachers, all three Normal Universities implemented character training programs that required pre-service teachers to wear a uniform and to attend a flag-raising ceremony each morning. In addition, students needed to participate in extra curriculum activities at Normal Universities including sports tournaments and drama competitions staged among different departments. These activities were aimed to cultivate pre-service teachers' character, cooperation, submission, and patriotism, so that they could become good role models in the high schools and could implement the ROC government's goals for educating future citizens.

An overall examination of the early history of the preparation of pre-service elementary teachers shows that the Taiwanese government has made significant changes three times as they have formalized elementary teacher preparation to transition from normal schools, to junior normal colleges to full universities. In each case, the goal has been to promote the quality of pre-service teachers both as good role models in schools and as professionals with improved content knowledge.

\section{The immediate past (IPs): 1994 till 2017}

After the government completely ended Marshal Law in 1991, society was becoming more open and the social atmosphere was changing. The government lifted bans on publishing newspapers and establishing TV stations and society was able to access mass media with limited restrictions. As a result, Taiwanese society quickly transformed into a democratic society. This had an important impact on education too as the government abolished old regulations pertaining to normal education and in 1994, enacted a new Teacher Education Act [TEA] (Teacher Education Act, 2014), which initiated multiple types of teacher education. 
The TEA allowed other universities, in addition to, teacher colleges and Normal Universities to prepare K-12 teachers and the law made changes in the methods for recruitment, training, and employment of teachers. The main historical events are shown in Fig. 2.

Before 1994, the Taiwanese government adopted a protectionist and centralized philosophy to govern teacher education. This kind of normal education system was concentrated on planned, government supported tuition, and government dissemination of pre-service teachers to schools. After the TEA in 1994, the teacher education system was transferred to a decentralized, self-financed system for preparation, qualification and certification of teachers (MOE 2012). All qualified universities with teacher education centers could prepare teachers (MOE 1995). Before 1994, there were only three Normal Universities and nine teachers' colleges prepared for secondary school and elementary school teachers. However, after this period, teacher education centers increased significantly. In 2018, the MOE recognized 13 private universities, 19 public universities and 8 teachers' colleges for preparing secondary teachers. In terms of preparing elementary school teachers, the MOE recognized 4 private universities, 2 public universities and 10 teachers' colleges.

Today more universities have established teacher education programs to prepare high school teachers, but the three original Normal Universities still play a major role to prepare future science teachers. Additionally, teacher education centers have become an important channel for providing teacher education programs via universities. This has led more traditional teacher preparation institutions to become more diverse. Today, this means that as long as an individual wants to become a teacher, he/she can take advantage of various opportunities to enroll in teacher education programs.

\section{Changes in teacher certification process}

In order to control the quality of pre-service teachers, the government implemented a new teacher certification examination process (MOE 2012). Under the new TEA (Teacher Education Act, 2017), all the qualified teacher education centers could

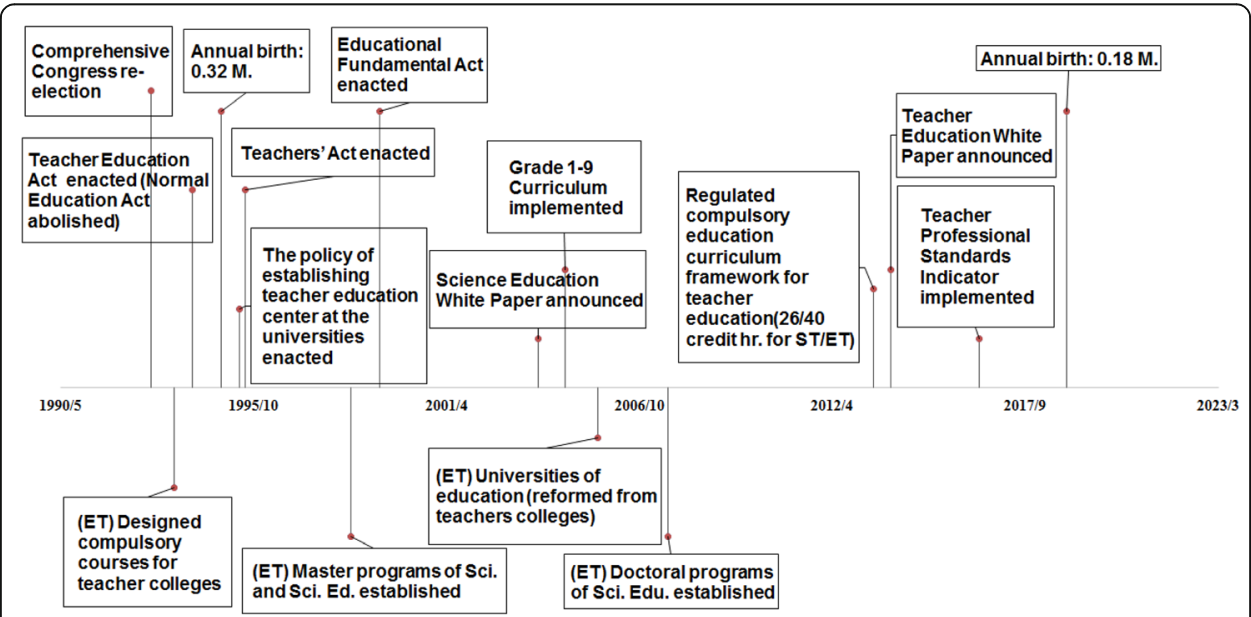

Fig. 2 The historical landmarks during the immediate past stag (IPs): 1994-2017 (ST: secondary teacher; ET: elementary teacher) 
educate pre-service teachers through programs that generally lasted 2 years and required 26 credit hours of for secondary teachers and 40 credit hours for primary teacher education coursework. General courses included, Foundations of Education, Educational Methodologies, discipline specific Teaching materials and Methods, Teaching Practicum, and 12 credit hours of elective courses. Many science departments from normal universities offered courses like high school chemistry inquiry teaching, biology laboratory teaching, biology teaching theory and practice, and introduction of science education. As a result, pre-service science teachers had diverse options to choose courses they wanted to prepare their teaching competency.

However, only science departments from the three Normal Universities or teacher colleges which had been certified by the MOE as teacher preparation departments could offer these options courses. For other teacher centers, only general courses for pre-service teachers could be offered. Regardless of which program prospective teachers were enrolled, once they completed their coursework, they had to finish a semester of intern teaching, and then they needed to pass a certification exam to receive either a secondary or elementary teacher certification. Once a teacher received certification, they became qualified teachers and needed to search for placements by themselves as the government no longer assigned teachers to a position and teaching jobs were no longer guaranteed. The new teacher education system provided many ways to control teacher quality, including, the elementary and secondary certification systems, internship evaluations, and assessment of course work. This new reform made the teaching profession more accessible and attractive.

\section{Impact on teacher certification process}

In the 1990s, the National Science Council in Taiwan began financing research in science teacher education. Funding for research sparked important areas of work related to the development of pre-service teachers' science teaching standards, standards for science teacher education programs, and evaluation methods for pre-service and internship science teachers. Other projects focused on using the Internet to improve science and math internship activities, and the development of distance mentoring systems to facilitate in-service teacher's professional development (Tuan et al. 2016).

Due to the TEA's open-policy, the MOE established a regulation for establishing teacher education programs. One regulation required that teacher education programs must be staffed by no less that than five instructors (assistant to full professor levels). In addition, for those instructors who were in charge of teaching methods courses or internships, they needed to have teaching experience in schools. As we can imagine, in the old teacher (normal) education system, all the teaching methods (chemistry teaching methods course, physics teaching methods course, etc.) as well as internship were covered by instructors with pedagogical content knowledge in a particular science areas. However, in the new system, pre-service teachers can only learn general pedagogy in the methods course (for instance, science teaching methods course or general teaching methods course) and the content areas instructors need to cover all discipline areas of pre-service teachers, therefore they can only supervise or teach them with general pedagogy teaching methods.

In terms of recruiting pre-service science teachers, the TEA required that after studying at the university for the first 2 years, students must take an examination to enroll 
in a teacher education program. For instance, an undergraduate who wanted to be admitted into a teacher education program required a high GPA or must rank in the top $40 \%$ in their homeroom class. This policy ensured that pre-service teacher program generally maintained a relative high academic quality.

While in the teacher education program, they needed to take 26/40 (secondary/elementary) credit-hour teacher education courses for at least two academic years. Noteworthy, in elementary teacher education program, non-science majored students were neither required to take any science courses, nor was science teaching methods listed as a mandatory course. This allowed students without a science major to teach elementary science with no proper training. Graduate students interested to enroll in teacher education programs also had to take an examination and after taking the required credit hours of the teacher education program, these pre-service teachers needed to participated in a half-year of intern teaching in the schools in which they wanted to become employed. Each teacher education program director needed to arrange for preservice teachers to participate in an internship. After a half-year internship, pre-service teachers could receive a first-stage teaching certificate. For the second stage certificate (also called teacher qualification), all pre-service teachers needed to take written examinations offered by the Department of Education in each county or each region (joined counties). Subjects of the examination are: Chinese competency tests, education principles and systems, child development and counseling (for elementary major)/adolescent development and counseling, elementary school curriculum and instruction (for elementary major)/or high school curriculum and instruction (for high school major), and a mathematical competence test (for elementary school major only) (MOE 2019c).

By 1994, the acceptance rates for elementary as well as high school teachers were very high, more than $70 \%$ of pre-service teachers could be selected as school teachers. These prospective teachers needed to apply for each school to present their teaching performance as well as their teaching portfolio. The MOE gradually changed the screening policy to group schools that needed to select teachers and offer teachers a unified examination process. Once teachers passed the written examination, they were offered the opportunities to present their teaching performance in front of the screening committee. These teachers would choose one science topic in elementary/high school, and then teach in front of the committee members. Committees consisted of experience school teachers, principals and university professors.

\section{Development of professional teaching standards}

To maintain quality control for teacher education centers, the MOE established 10 teacher's professional standards indication in 2016 to guide the implementation of teacher education programs (See Table 1) (MOE 2016).

The MOE uses these standards as a guideline to evaluate teacher education centers, internship experiences and pre-service teacher education program. Although these teaching standards were mainly developed by educators to match teachers in all disciplines areas, these standards are also well aligned to good science teaching pedagogical content knowledge (Tuan et al. 2016). Science teachers need to hold strong science subject matter knowledge, know their students' science learning characteristics and learning difficulty, design the lesson to match different learning ability students' needs. 
Table 1 Teacher professional standards

\begin{tabular}{|c|c|}
\hline Standards & Criteria \\
\hline $\begin{array}{l}\text { Standard } \\
1\end{array}$ & Acquire educational professional knowledge and to catch important education issues. \\
\hline $\begin{array}{l}\text { Standard } \\
2\end{array}$ & $\begin{array}{l}\text { Acquire discipline/content knowledge and content related teaching competency. } \\
\text { a. To acquire teaching discipline/content specific knowledge. } \\
\text { b. To acquire teaching discipline/content specific teaching competency. }\end{array}$ \\
\hline $\begin{array}{l}\text { Standard } \\
3\end{array}$ & $\begin{array}{l}\text { Acquire curriculum and teaching design competency } \\
\text { a. To refer curriculum standards and students' characteristics to establish teaching goals, and } \\
\text { implement curriculum and teaching plans. } \\
\text { b. To base on students' learning progress and needs, flexibly adjust teaching design and } \\
\text { materials. } \\
\text { c. To integrate knowledge, concepts and living experience, active content to be taught. }\end{array}$ \\
\hline andard & $\begin{array}{l}\text { To flexibly implement teaching strategies in order to make effective teaching. } \\
\text { a. To apply appropriate teaching strategies and communication skills to help students' learning. } \\
\text { b. To apply multiple teaching media, information technologies and resources to facilitate } \\
\text { teaching. } \\
\text { c. According to students' learning performance, accept remedy strategies or to supply in-depth } \\
\text { or wider learning strategies. }\end{array}$ \\
\hline $\begin{array}{l}\text { Standard } \\
5\end{array}$ & $\begin{array}{l}\text { To apply appropriate methods to conduct learning evaluation. } \\
\text { a. To adopt appropriate evaluation instruments or varied information, to assess students' } \\
\text { competency and learning. } \\
\text { b. To apply the evaluation results to give students' learning feedback and to improve teaching. } \\
\text { c. To change the evaluation methods based on students' physical and mental characteristics and } \\
\text { special learning needs. }\end{array}$ \\
\hline andard & $\begin{array}{l}\text { Apply classroom management efficacy to create a supportive learning environment. } \\
\text { a. To establish classroom regulation, and to establish learning environment to facilitate learning. } \\
\text { b. To create good teacher student interactive learning situation, establish caring and friendly } \\
\text { learning atmosphere. } \\
\text { c. To control classroom learning condition, handle classroom discipline problem appropriately. }\end{array}$ \\
\hline $\begin{array}{l}\text { Standard } \\
7\end{array}$ & $\begin{array}{l}\text { To control students' difference and conduct relevant counseling. } \\
\text { a. To understand students' background difference and interests, guide students to adapt } \\
\text { learning and development. } \\
\text { b. To understand students' culture, guide students' to establish positive social learning. } \\
\text { c. To respond to different patterns of students' needs and provide essential support and } \\
\text { counseling. }\end{array}$ \\
\hline $\begin{array}{l}\text { Standard } \\
8\end{array}$ & $\begin{array}{l}\text { To consciously responsible for education professional responsibility } \\
\text { a. Express enthusiasm for education, caring for students' learning rights and development. } \\
\text { b. Follow teacher professional ethnic and relative law regulation. } \\
\text { c. Caring for school development, engagement school affairs and meeting. }\end{array}$ \\
\hline $\begin{array}{l}\text { Standard } \\
9\end{array}$ & $\begin{array}{l}\text { Devote to teacher professional development } \\
\text { a. Reflect professional practice, try to explore and solve problems. } \\
\text { b. Attend teaching research/in-service workshop, continue mastering teaching, and to enhance } \\
\text { students' learning. } \\
\text { c. Attend professional learning community, professional development organization, and enhance } \\
\text { professional development. }\end{array}$ \\
\hline $\begin{array}{l}\text { Standard } \\
10\end{array}$ & $\begin{array}{l}\text { Express cooperative and leadership ability } \\
\text { a. Attend peer teachers' interaction, co-develop curriculum and teaching project, express co- } \\
\text { operative and leadership ability. } \\
\text { b. Establish the relationship among parents and community partnership cooperative relationship. } \\
\text { c. To adapt the needs from school, participate in school organization and development work, } \\
\text { develop leadership ability. }\end{array}$ \\
\hline
\end{tabular}

In addition, they need to know the school culture and constantly develop their teaching competency to fit the school and local culture. Most of the MOE's standards were based on science education research and teaching professional standards reflecting research findings from the past 20 years (Tuan et al. 2016). For instance, Wang (2006) used the Delphi method to explore elementary school science and math teachers' professional development standards and identified four major standards: educational philosophies, subject matter knowledge, teaching and assessment, and professional 
development. Chin (2009) used the Delphi method to investigate 32 science teacher educators' perception of good indicators to evaluate science teacher education programs, and they found that educators believed the most important program features are the recruiting process of preservice teachers, providing good internship experiences, the nature of supervision, professors' competence in teacher education programs, and preservice science teachers' attitudes toward teaching and teaching competencies.

After the TEA, in 2008, the MOE helped three Normal Universities establish in-service teaching programs to encourage in-service teachers to promote their teacher professional development [TPD]. Tuan et al. (2016) describe how these in-service TPDs should include a master degree graduate program to encourage in-service science teachers studied in the areas of educational administration, education or teaching. In 1987, NTNU and NCUE established graduate institutes of science education offering doctoral program and master's program. In these science education graduate programs, graduate students needed to take a science education seminar, special issues in science education, theories related to science education, specific science teaching methods (conceptual change, constructivism, etc.), research methodologies courses, and thesis writing. Many in-service science teachers applied research methodologies to examine their science teaching or implement new science teaching.

By 1998, teachers' colleges established graduate institute of science education master's programs and in 2007 established the first doctoral programs. Until 2007, there were 11 Normal Universities and teachers' colleges offering science education graduate programs. As a result, many in-service elementary and secondary school science teachers have been well trained in science teaching as well as in writing. In addition, certification-programs encourage in-service teachers to study a second major and to attend in-service workshops at local schools to meet local school teachers' needs. Science teachers have to take a certain number of credit hours per year (the number varies in each county) to prove they are working on their professional development requirements. Tuan et al. (2016) reviewed research literature in Taiwan on the impact of TPDs and found that science TPD offerings can be classified into the following areas: enhancing teachers' constructivist teaching competencies, inquiry-based teaching competencies, and technology competencies. In addition, numerous action research theses have been produced which shows increased attention on teacher's reflective practices.

\section{The present and future (PF): 2018 and beyond}

In this section, we describe the impact of past changes on the present and we highlight some challenges to address in the future. Based on the changes under the TEA, we see that the strengths of teacher education have been increased diversity and quality control (including the recruiting of pre-service teachers, certification, and program evaluation). However, we have seen a decrease in pedagogical content knowledge enhancement in the new teacher education system. Due to a lack of instructors with pedagogical content knowledge in each science discipline area for teacher education centers, which have different requirements than Normal Universities or teachers' colleagues As a result, some pre-service science teachers may have fewer experiences to practice and improve their pedagogical content competency.

Unlike the older system, elementary teachers with science majors are not accredited as "elementary science teachers" and so they are not guaranteed to have the privilege to 
teach science in elementary schools. This change has resulted in teachers who have majored in topics like physical education or arts education to also have the obligation to teach science. Unfortunately, many of these non-science major teachers do not take any science teaching related courses. This has left many elementary students in the hands of teachers with insufficient science training (Liu and Chen 2013). This change was seen as a danger to the quality of science teaching in Taiwan. So the MOE initiated a new policy in 2015 to start recognizing science as a specialized teaching subject in elementary schools (MOE 2015).

While this has not completely corrected the problem, but has opened a possibility of improving the quality of elementary science education in Taiwan by having science courses taught by teachers more competent in science. Tables 2 and 3 demonstrate how changes in policy have impacted on science teacher preparation over the last 20 years.

Based on the above Table 2 (MOE 2019a), we can see that in 1999, only 5 years after the TEA was passed, only $4.13 \%$ of elementary school teachers and $7.00 \%$ of junior school teachers had a graduate degree. However, by 2011, the percentage of elementary school teachers receiving graduate degrees was had increased to $35.06 \%$ and to $33.39 \%$ for junior high school teachers. By 2017 , nearly $60 \%$ of all teachers held a graduate degree. This data shows there has been an increase in teachers' professional development and that becoming an elementary or junior high school science teacher is harder than before.

When we examine the data based on gender (Table 3, MOE 2019b), we also see that science and living technology teachers, at both the elementary and junior high school levels, are mostly males. However, from 2006 to 2017, the percentage of female science teachers and living technology teachers in junior high schools has increased. But we also see that by 2017, the enrollment level for science and living technology has dropped significantly with only 6692 teachers.

When we examine what percentage of teachers pass the qualification exams in 20152017 (Table 4), we see that a little more than half of all elementary $(43.92 \%-58.28 \%)$ and secondary teachers $(49.47 \%-60.54 \%)$ passed the exam. This means that about half of all pre-service elementary and secondary school teachers can receive their teachers' qualification certification.

However, most of these teachers cannot be placed in schools (Table 5). In the same time period, around $10 \%$ of qualified elementary teachers, $5 \%$ of qualified junior high school teachers, and $6 \%$ of qualified senior high school teachers were employed.

For recruiting science teachers, only around $5 \%$ of qualified science teachers were enrolled in junior and senior schools (Table 6) in the same time period. This means that

Table 2 Elementary and junior high school teachers' with graduate degree

\begin{tabular}{|c|c|c|c|c|c|c|}
\hline \multirow[b]{2}{*}{ Year } & \multicolumn{3}{|c|}{ Elementary school teacher } & \multicolumn{3}{|c|}{ Junior high school teachers } \\
\hline & Number & $\begin{array}{l}\text { With graduate } \\
\text { degrees }\end{array}$ & $\%$ & Number & $\begin{array}{l}\text { With graduate } \\
\text { degrees }\end{array}$ & $\%$ \\
\hline 1999 & 98,745 & 4083 & $4.13 \%$ & 50,190 & 3515 & $7.00 \%$ \\
\hline 2005 & 101,662 & 12,351 & $12.15 \%$ & 48,797 & 8101 & $16.60 \%$ \\
\hline 2011 & 98,559 & 34,551 & $35.06 \%$ & 51,200 & 17,095 & $33.39 \%$ \\
\hline 2017 & 94,403 & 54,017 & $57.21 \%$ & 46,770 & 26,701 & $57.10 \%$ \\
\hline
\end{tabular}

(MOE 2019a) 
Table 3 Elementary and junior high school science and living technology teachers' population

\begin{tabular}{|c|c|c|c|c|c|c|}
\hline \multirow[b]{2}{*}{ Year } & \multicolumn{3}{|c|}{ Elementary school } & \multicolumn{3}{|c|}{ Junior high school } \\
\hline & $\begin{array}{l}\text { Total no. of } \\
\text { teachers }\end{array}$ & Male teacher (\%) & Female teacher (\%) & $\begin{array}{l}\text { Total no. of } \\
\text { teachers }\end{array}$ & Male teacher (\%) & $\begin{array}{l}\text { Female teacher } \\
\text { (\%) }\end{array}$ \\
\hline 2006 & 8755 & $4738(54.12 \%)$ & 4017 (45.88\%) & 7995 & 4718 (59.01\%) & $3277(40.99 \%)$ \\
\hline 2007 & 8728 & $4727(54.16 \%)$ & 4001 (45.84\%) & 8556 & 5075 (59.32\%) & 3481 (40.68\%) \\
\hline 2008 & 8611 & 4631 (53.78\%) & 3980 (46.22\%) & 8484 & $5033(59.32 \%)$ & 3451 (40.68\%) \\
\hline 2009 & 8583 & 4681 (54.54\%) & $3902(45.46 \%)$ & 8457 & 4988 (58.98\%) & 3469 (41.02\%) \\
\hline 2010 & 8393 & $4626(55.12 \%)$ & 3767 (44.88\%) & 8397 & 4938 (58.81\%) & 3459 (41.19\%) \\
\hline 2011 & 8219 & 4450 (54.14\%) & 3769 (45.86\%) & 8207 & 4803 (58.52\%) & $3404(41.48 \%)$ \\
\hline 2012 & 8391 & $46685(5.63 \%)$ & $3723(44.37 \%)$ & 7911 & 4606 (58.22\%) & 3305 (41.78\%) \\
\hline 2013 & 7996 & 4371 (54.66\%) & 3625 (45.34\%) & 7889 & $4561(57.81 \%)$ & 3328 (42.19\%) \\
\hline 2014 & 8248 & $4501(54.57 \%)$ & $3747(45.43 \%)$ & 7687 & $4463(58.06 \%)$ & 3224 (41.94\%) \\
\hline 2015 & 8133 & 4359 (53.60\%) & 3774 (46.40\%) & 7368 & $4244(57.60 \%)$ & 3124 (42.40\%) \\
\hline 2016 & 7861 & 4357 (55.43\%) & 3504 (44.57\%) & 6944 & 3975 (57.24\%) & 2969 (42.76\%) \\
\hline 2017 & 7979 & 4377 (54.86\%) & 3602 (45.14\%) & 6692 & 3801 (56.80\%) & 2891 (43.20\%) \\
\hline
\end{tabular}

(MOE, 2019b)

among the $50 \%$ of teachers who qualified for employment, less than $10 \%$ we actually employed. The remaining teachers cannot be officially employed in schools.

Many of these teachers seek positions as substitute teachers in schools or work to develop other careers related to education, but this low employment phenomenon causes many problems in society and creates obstacle for university students to become teachers (MOE 2012).

\section{Challenges for the future}

Today, the education system has undergone many changes, which bring some challenges and benefits. In addition to what we have discussed previously, in this section we will describe some current changes and issues that are impacting on teachers in Taiwan. Recently, with the trend of educational globalization, the MOE has opened a door for pre-service teachers who complete all pre-service courses required from foreign universities at the bachelor's level or higher to also be recognized by the MOE. These teachers, who are educated abroad, can receive a Pre-service Teacher Education Completion Certificate. This will certainly provide a new way to energize and innovate education in schools, but can cause some inequities in educational opportunities because not all prospective teachers can afford to study abroad. Another continuing challenges for Taiwan's education system is the need to continually develop and appreciate

Table 4 Elementary and secondary school teachers' qualification examination passing rate during 2015-2017

\begin{tabular}{|c|c|c|c|c|c|c|}
\hline \multirow[t]{2}{*}{ Year } & \multicolumn{3}{|c|}{ Elementary teacher } & \multicolumn{3}{|c|}{$\begin{array}{l}\text { Secondary (junior +senior high) } \\
\text { School teacher }\end{array}$} \\
\hline & Examinee & Passed & Passing rate & Examinee & Passed & Passing rate \\
\hline 2015 & 2227 & 978 & $43.92 \%$ & 3735 & 2261 & $60.54 \%$ \\
\hline 2016 & 2393 & 1326 & $55.41 \%$ & 3954 & 1956 & $49.47 \%$ \\
\hline 2017 & 2337 & 1362 & $58.28 \%$ & 4342 & 2479 & $57.09 \%$ \\
\hline
\end{tabular}

(MOE 2016, 2017, 2018) 
Table 5 Employment rate during 2015-2017-elementary, junior and senior high school teachers

\begin{tabular}{|c|c|c|c|c|c|c|}
\hline \multirow[t]{2}{*}{ Year } & \multicolumn{2}{|c|}{ Elementary schools } & \multicolumn{2}{|c|}{ Junior high schools } & \multicolumn{2}{|c|}{ Senior high schools } \\
\hline & Examinee & Admitted rate (\%) & Examinee & Admitted rate $(\%)$ & Examinee & Admitted rate (\%) \\
\hline 2015 & 15,855 & 1607 (10.14\%) & 8535 & $682(7.99 \%)$ & 9841 & $702(7.13 \%)$ \\
\hline 2016 & 16,308 & $1700(10.42 \%)$ & 6571 & $242(3.68 \%)$ & 9812 & $594(6.05 \%)$ \\
\hline 2017 & 14,445 & 1557 (10.78\%) & 4001 & $181(4.52 \%)$ & 10,028 & 500 (4.99\%) \\
\hline
\end{tabular}

(MOE 2016, 2017)

the different cultures and groups of minorities living in Taiwan. In recent years, the government has paid a lot of attention to aboriginal education and has emphasized the need for future teachers to be trained to educate students with divergent needs, including the needs of aboriginal students. In fact, during the past 10 years, the Ministry of Science and Technology has promoted an aboriginal science education program that supports a varied cultural response science curriculum that has attempted to integrate more indigenous views of science into the curriculum. Finally, there are more government-funded scholarship opportunities for pre-service teachers. Unlike the funding offered in the past, these current programs only waive tuition and the recipients are required to teach in rural country schools for 5 years after their graduation.

As of 2019, a new curriculum started to be implemented in all grades from elementary to high school. In the new curriculum, one emphasis is on inquiry and practicebased instruction. Science teachers (grades 1 to 12) need to enhance students' thinking abilities (imagination and creativity, reasoning and argumentation, critical thinking and modeling), problem solving abilities (observing and identifying; planning and executing; analyzing and finding; discussing and communicating), and attitudes toward science and the nature of science (interest in science, habit of scientific thinking and inquiry, nature of science). Unfortunately, the new curriculum has reduced science in the junior high level, as there are now three science classes per week and each class lasts for $45 \mathrm{~min}$. The previous curriculum included $4 \mathrm{~h}$ of science a week and there has been a change in the course work offered. The science education community in Taiwan has raised this as a concern and seeks to expand science instruction again (Lien et al. 2018). Additional changes include the requirement that science teachers in senior high schools are now required to teach $1 \mathrm{~h}$ of science inquiry and practice per week. This requires that teacher education programs prepare pre-service and in-service science teachers with inquirybased teaching competencies and with the skills to integrate different disciplines into the curriculum. Currently this is a challenge for science teacher education in Taiwan.

In order to implement the new curriculum, $\mathrm{MOE}$ has integrated various projects and expanded the budget for professional development to help enhance in-service science teachers' inquiry-based teaching competencies, such as inquiry-based instructional

Table 6 Science and living technology teachers during 2015-2017_-junior high schools \& senior high school teachers

\begin{tabular}{llllllll}
\hline Year & \multicolumn{3}{l}{ Junior high schools } & & \multicolumn{3}{l}{ Senior high schools } \\
\cline { 2 - 3 } & Examinee & Admitted & Admitted rate (\%) & & Examinee & Admitted & Admitted rate (\%) \\
\hline 2015 & 921 & 54 & $5.86 \%$ & 1337 & 99 & $7.40 \%$ \\
2016 & 718 & 24 & $3.34 \%$ & & 1383 & 84 & $6.07 \%$ \\
2017 & 465 & 27 & $5.81 \%$ & 1503 & 71 & $4.72 \%$ \\
\hline
\end{tabular}

(MOE 2016, 2017, 2018) 
design and inquiry-based teaching and assessment. The MOE invited all science educators to publish science teaching methods textbooks from elementary level to junior high school level in different science disciplines that can be used in the future teacher education center. All of these textbooks were integrated with science education research, classroom teaching practice and science education theories. Many of these textbooks have embedded within them inquiry-based instruction as well as applying technology. For the in-service science teacher education programs, many new courses related to inquiry-based teaching methods are being offered. At this moment, these projects are still undergoing. We hope these projects provide positive and fruitful outcomes for teaching and learning in the near future.

From a societal perspective, many issues, including the aging society, low birth rates, and low hiring rates for teachers (MOE 2012) are presenting many new challenges for teacher education in Taiwan. These changes mean that the number of students enrolling in teacher education programs is decreasing and teacher educators are working hard to attract students who want to be science teachers in the future. Fortunately, due to the competitive recruiting process, prospective teachers need to have strong commitment and solid preparation to be hired as school teachers - so the quality of teachers being produced is quite high. In addition, given the competition for maintaining employment and professionalism, current science teachers are starting to update their teaching certifications and are beginning to work on a second certificate (such as living technology, computer science) in order to keep their jobs at the same schools. In general we see science teachers exercising more autonomy in their professional growth and we have higher overall standards for teaching and learning.

\section{Conclusions and implications}

This paper has focused on analyzing observed phenomena in the current educational system and proposed directions for future development. In general, society and education are developing to be more open, politically polar, gender-equitable, and reliant on scientific and technology-related industries. In education, specifically, there is a tendency for science teachers to be more autonomous in their professional growth and teaching practices. Today, expectations towards elementary and secondary science education continues to increase, with diversifying and broadening teaching contents, more effective and efficient educational technology, and more diversified and reinvigorated science teachers in the community.

In these contexts, based on existing information and observations (DPs and IPs), this study asks RQ1. How did the external social and political factors (i.e., the rationale of education, educational system, the perception of science teachers) impact teacher education in Taiwan?

In 1949, the government of the Republic of China (ROC) retreated to Taiwan and implemented Martial Law. During this period, the government's primary task was to maintain Taiwan's security and restore the mainland. Thus, inside the educational system, education was considered a form of spiritual national defense. The educational administration, curriculum, and instructions were all in centralized control. Furthermore, during this period, the government not only pragmatically upgraded the level of teacher education institutes but also emphasized the balance of teacher training institutions in 
Taiwan geographically. These institutions played crucial roles in preparing teachers for the needs of the phased task. For science teachers, their responsibilities were mainly teaching the content of the national curriculum to students.

Because of the easing relations between Taiwan and Mainland China in 1987, Taiwan relieved Martial Law and implemented the Comprehensive Congress Reelection in 1992. This reelection reconstructed the old parliament, which was not elected by Taiwanese residents, and challenged the old model of centralization, moving the Taiwanese society toward decentralization, autonomy, and pluralism. This change in power and mind-set cultivated the Teacher's Act of 1994, which allowed all universities to prepare school teachers and subvert the original teacher education system.

Moreover, the "curriculum standards" were changed to "curriculum guidelines," which gave teachers more teaching autonomy. The overall mind-set of science teachers was transformed from the traditional "be normal" perspective to a more diverse one. This allowed teachers to play an exemplary role in education, but they were also expected to enrich the curriculum and implement adaptive teaching. The change shows that external social and political situations influence the preparation of science teachers, and this includes the positioning and teaching practices of science teachers. In light of the future development of Taiwanese society, Taiwan's education is expected to require more drastic changes. Therefore, educational administrators and science educators need to plan, i.e., to draw an ideal model of science teachers for future needs; formulate strategic plans of organizational and curriculum development; restructure the certification, employment, and professorial growth system for science teachers; and respond to the call and needs of external social, economic, and political situations.

In response to RQ2. What are the characteristics of the educational system and curriculum of Taiwan's science teacher education in the past, present, and what are their implications for the future?, this study examined the transitions in preservice science education in the periods of DPs and IPs in Taiwan. Also, this study observed and assessed the characteristics of the curriculum design in science teacher education programs. We found that the number of institutions, under the central government's planning scheme that trained science teachers were minimal, but somewhat regionally balanced. The elementary and secondary teachers were trained in distinctly different universities/colleges. Many changes, such as the dramatic increase then decrease in the number of teacher education institutions, occurred during the period of DPs.

In the aspect of the level and name of the organization, the DPs stage has upgraded the training of elementary teachers from junior colleges to four-year full colleges. The training of secondary school teachers was done in four-year colleges and then became full universities. Science teachers were trained in departments of physics, chemistry, biology, geology, etc. Many of these departments also offered master and doctoral programs. In the IPs stage, the elementary teacher education institutes divided their department of science and mathematics education into two separate departments. Later, they began to set up master and doctoral programs, which served as relevant channels for the professional growth of elementary science teachers.

In the aspect of the preservice curriculum, during the DPs period, the curriculum goal of preservice science teacher education was directly for teachers with sufficient science teaching ability. However, in the IPs period, not all students can get a teaching job, and the departments cannot have only one curriculum for preparing science 
teachers. The first curriculum design needed to consider the many students who are not going to be science teachers, while the second one should consider those who will become science teachers. However, this adjustment made science teacher curricula design relatively unimportant. Although this transition was realistically justified, it profoundly affected the structure and content of the curriculum for science teacher preparation. This problem persists today. Therefore, the design of future preservice education curricula for science teachers should not be merely choosing from the paths of DPs or IPs. Following the DPs curriculum path would only achieve a minuscule rate of students entering the workplace, letting most students spending four or 6 years in higher education, which is not useful in their future job. This is a waste of time and disrespect for learners. On the other hand, following the IPs curriculum path would lead to teacher education institutes (e.g., universities, departments, and programs) wherein the science teacher education curriculum is treated as merely as an attachment, with students possibly considering the teacher education curriculum as minor. Under this circumstance, it would be unlikely to expect a design for an ideal science teacher education curriculum and to have devotedly competent science teachers. Therefore, the education administration and teacher-training institutions should conduct in-depth research and form policies regarding the educational system, employment quantity, and curriculum distribution. More importantly, they should focus on the structure and content of the science teacher education program. By doing this, it would more likely result in more world-class science teachers in the future, aiding societal development.

Lastly, the study asked RQ3. What are the changes in Taiwan's teacher and career development for science teachers in the past and present, and what are their implications for the future? In DPs and IPs, the mechanisms and situations of entering teaching jobs have changed dramatically. At the DPs, almost 100\% of all science teachers who received preservice teacher education were assigned to elementary and secondary schools and became teachers. However, this situation was not applicable anymore in IPs, and the employment rate has dropped by about $10 \%$ in elementary and junior high schools, respectively. Considering that teacher selection in elementary schools usually did not specify teaching subjects, the ratio of qualified science teachers in elementary schools was not appropriately controlled. Although there are already a few large counties and cities starting to recruit teachers with science expertise, this recruitment still has to be popularized. In addition to the state of employment, the proportion of male and female science teachers did not shift. This might be a synthesized result from government policies, subject preference, and valuing gender equality. This gender-related issue should be further studied and continuously monitored.

Another important aspect to focus on is the mismatch with the lessening number of science teachers teaching in elementary schools and the presence of non-science major teachers who could teach science. This had long been in existence in DPs and IPs and is still a problem waiting to be solved. In relation to professional development, in the early DP period, the belief that teachers should be devoted to professional growth was widely accepted, such as studying for higher degrees or attending government-required workshops. However, the offered training is mostly done in formal education institutes and government in-service training institutes. Aside from these, teachers' autonomous in-service training received more attention. For these reasons, the Ministry of Education established a flexible regulation in 1986 to encourage and require in-service 
teachers to have about $18 \mathrm{~h}$ of in-service training. However, because of the restrictions on what courses should or should not be recognized, this provision was eventually abolished after 7 years. In the IPs period, science teachers are still studying for higher degrees, but until the middle and late IPs, large portions of teachers already had master degrees. Thus, for the future, it is necessary to identify how formal education institutes have contributed and/or can contribute more to teachers' professional growth, and what forms and regulations in informal education can be beneficial to science teachers' professional growth.

The concept of a $100 \%$ preservice science teacher assigned with a teaching job, like that in the DPs period, is not feasible today. In contrast, with the LPs period, there were about $90 \%$ of the preservice teachers that may not find a teaching job and be unwilling to find other employment, which shows how the years they spent do not necessarily translate to better career performance. In the current situation, science teacher employment, assignment, and career development remains a major challenge. Teacher education, as well as the science teacher education system, is developing emerging needs for restructuring. The change will decide whether pre- and in-service science teachers could become more internationally competitive and develop more sustainable and fulfilling teaching careers.

In Taiwan, there is a very famous saying “良師興國 (Good teachers rejuvenate the country)." The Confucius philosophy has affected people's thinking in Taiwan. Therefore, teachers are well respected in the Taiwanese society. Although the teacher education system has dramatically changed, a comparative study showed that the general public in Taiwan still consistently and highly supports schools (Lu and Lien 2016) and the teaching profession is still regarded as a highly respectable profession in Taiwan (Otsuji et al. 2016).

Looking back over 70 years of teacher education and science teacher education development in Taiwan has revealed that we will continue to face changes in policy and the need to prepare and recruit qualified science teachers in the future. Therefore, issues such as how to select proper students for science teacher education programs; what programs could prepare competent science teachers for the next decades; how could we maintain a reasonably competitive job environment so that not so many young people need to waste their time on unfruitful career pursuing, etc., are all issues of great importance. It is apparent that science teacher education has a lot of room for improvement.

An old saying in Taiwan goes, “十年樹木, 百年樹人 (In ten years, we can plant trees, in a hundred years we can cultivate the next generation)." Whether the vivid, and dynamic new teacher education system could cultivate pre-service teachers to become good science teachers and provide them with a long-supporting system would be a challenge for science teacher educators to keep track of in the future.

Acknowledgements

Not applicable.

Authors' contributions

All authors contributed equally to this work. All authors commented on the manuscript at all stages. Both authors read and approved the final manuscript. 
USA. Her research focused on science teachers' professional development, science teachers' inquiry-based teaching, students' science learning motivation, and lower track students' science learning. She has severed NARST association as International Coordinator, JRST associate editor. In Taiwan, she has served as president of Science Education Association in Taiwan, and chief editor of Journal of Science Education in Taiwan.

Yu-Ling Lu is a Professor in the Department of Science Education at the National Taipei University of Education, Taiwan, with a bachelor's degree in physics, a master's degree in chemistry, and a doctoral degree in science education. She published articles in the fields of educational policy, science curriculum development, instructional design, and technology- enhanced learning. In 2018, she began to serve as the chairperson of the Association of Science Education in Taiwan, a research group devoted to promoting the quality of science education research among many areas of the academe.

\section{Funding}

Not applicable.

\section{Availability of data and materials}

All data discussed is available from sources cited in the paper. The data sets can be made available from the corresponding author on reasonable request.

\section{Ethics approval and consent to participate}

The data collected from this article did not involve human subjects so no human subjects approval was necessary.

\section{Consent for publication}

The authors agree that this article will be published in the APSE journal.

\section{Competing interests}

The authors declare that they have no competing interests.

\section{Author details}

${ }^{1}$ Graduate Institute of Science Education, National Changhua University of Education, Changhua City, Taiwan.

2Department of Science Education, National Taipei University of Education, Taipei City, Taiwan.

Received: 9 August 2019 Accepted: 13 November 2019

Published online: 09 December 2019

\section{References}

Chin, C. C. (2009). The development of secondary science teacher education organizations' evaluation standards. Chinese Journal of Science Education, 17(4), 275-292.

Cheng, Y. J. (2006). The introduction of integration projects under "Multiple teacher education system with science and math teachers' certification and preparation models". National Science Council Monthly, 25(6), 263-372.

Darling-Hammond, L. (2000). Teacher quality and student achievement: a review of state policy evidence. Education Policy Analysis Archives, 8(1), 1-44.

Department of Education, Taiwan Provincial Government. (1987a). 台灣省政府教育廳編. 台灣教育發展史料彙編師範教育 編(上冊) [Taiwan Education Development History Compilation- Teacher Education (Volume 1)]. Taichung: Author.

Department of Education, Taiwan Provincial Government. (1987b). 省(市)立師範學院課程總網、各學系(組)課程表 [Curriculum Guideline for Provincial (Municipal) Teachers Colleges; Curium Framework for Departments]. Taichung: Author.

Druva, C. A., \& Anderson, R. D. (1983). Science teacher characteristics by teacher behavior and by student outcome: a metaanalysis of research. Journal of Research in Science Teaching, 20(5), 467-479.

Fwu, B. J. (1995). Teacher training in Chinese Taipei. In L. Darling-Hammond \& V. L. Cobb (Eds.), Teacher preparation and professional development in APEC members: a comparative study (pp. 207-220). Washington, DC: The US Department of Education.

Hung, F. T. (2018). 台灣省立台北師範學校 [Taiwan Provincial Taipei Normal School]. In Y. W. Chou \& H. S. Peng (Eds.), 台灣 小學師範教育發展(師範學校篇) [Development of Taiwan Elementary School Teacher Education (Normal Schools)] (pp. 71-138). Taipei: Pro-Ed Publishing.

Lee, T. Y. (1992). 國小職前教師基本自然科學知識及自然科教學態度之研究 [The preservice elementary school teachers attitude toward science teaching and its relationships with selected variables]. 師大學報 [Journal of National Taiwan Normal University], 37, 529-577.

Liang, S., \& McClain, C. J. (1991). Teacher education. In D. C. Smith (Ed.), The Confucian continuum: educational modernization in Taiwan (pp. 277-316). New York: Praeger.

Lien, C.-J., Lee, H., Lee, S. T., Lin, S. F., Liu, S. C., Cheng, M. T., She, H. C., et al. (2018). 十二年國民基本教育科學課程時數一國 際比較之摘要報告 [Sciences-course hours in 12-year basic education curriculum - a summary report based on an international comparison]. The E-News of the Association of Science Education in Taiwan Retrieved Sept. 17, 2019 from http://www.ase.org.tw/?menuid=9705\&lgid=2\&siteid=100495 (in Chinese). Accessed 11 Oct 2019.

Lin, C. J. (1983). The republic of China (Taiwan). In R. Thomas \& T. N. Postlethwaite (Eds.), Schooling in East Asia: forces and changes (pp. 104-135). Oxford: Pergamon Press.

Lin, T. J., Lin, T. C., Potvin, P., \& Tsai, C. C. (2019). Research trends in science education from 2013 to 2017: a systematic content analysis of publications in selected journals. International Journal of Science Education, 41(3), 367-387.

Liu, H. Y., \& Chen, Y. T. (2013). 台灣科學教育師資培育制度 [Taiwan science education teacher cultivation system]. In C.-Y. Lin \& R.-J. Wang (Eds.), 亞洲科學教育師資培育 [Science teacher education in the Asia Pacific region] (pp. 203-238). Taipei National Taiwan Normal University Press. 
Lu, Y. L., \& Lien, C. J. (2009). 國民小學自然科師資培育之回顧、現況與展望 [(The retrospect, presence and prospect of elementary school science teacher training)]. 國民教育 [Elementary Education], 50(1), 17-26.

Lu, Y. L., \& Lien, C. J. (2016). Elementary science education in Taiwan-From the perspective of international comparison. In M.-H. Chiu (Ed.), Science education research and practices in Taiwan (pp. 163-180). Singapore: Springer.

Ministry of Education. (1932). 師範學校法 [The Normal School Act]《the Normal School Act 師範學校法》. Naking: Author. Ministry of Education. (1947). 修正師範學校規程 [Amended Teacher Normal School Regulations]. Author: Naking.

Ministry of Education. (1993). 師範學院各學系必修科目表 [Compulsory Courses for Departments of Teacher Colleges]. Taiwan: Author.

Ministry of Education. (1995). 大學設立師資培育中心辦法 [The policy of establishing teacher education center at the universities]. [Electronic version]. Retrieved from https://law.moj.gov.tw/LawClass/LawAll.aspx?pcode=H0030030. Taiwan: Author.

Ministry of Education. (2012). 師資培育白皮書 [Teacher Education White Paper]. Taipei: Ministry of Education Taiwan: Author. Ministry of Education. (2015). 國民小學教師加註自然領域專長專門課程科目及學分對照表 [The cross reference courses list for elementary teachers adding natural science teaching as additional expertise]. Taiwan: Author.

Ministry of Education. (2016). 中華民國教師專業標準指引 [Republic of China teacher professional standards indicator]. Taiwan: Author.

Ministry of Education. (2017). 中華民國師資培育統計年報 [Republic of China Yearbook of Teacher Education Statistic]. Taiwan: Author [Electronic Version] Retrieved from https://ws.moe.edu.tw/001/Upload/8/relfile/7805/61513/4682f82c-16c8-428db017-cff5bf8cf17a.pdf.

Ministry of Education. (2018). 中華民國師資培育統計年報 [Republic of China Yearbook of teacher education statistic]. Taiwan: Author [Electronic version] Retrieved from https://ws.moe.edu.tw/001/Upload/8/relfile/7805/61513/4682f82c-16c8-428db017-cff5bf8cf17a.pdf.

Ministry of Education (2019a). 各級教育統計概況分析 [Analysis of the Statistics of Education at All Levels] [Electronic version] Retrieved from http://stats.moe.gov.tw/files/analysis/107_all_level.pdf

Ministry of Education (2019b). 性別統計指標彙總性資料--教職員 [Gender statistics indicators summary information faculty] [Electronic version] Retrieved from https://depart.moe.edu.tw/ED4500/cp.aspx?n=C1EE66D2D9BD36A5

Ministry of Education. (2019c). 高級中等以下學校及幼兒園教師資格考試簡章 [teacher qualification examination procedure for secondary, elementary and early childhood education (2019)]. Author: The brief of teacher qualification examination. Taiwan.

Ministry of Foreign Affairs (2019). The official website of the Republic of China. Retrieved from https:/www.taiwan.gov.tw.

Mullis, I. V. S., Martin, M. O., Foy, P., \& Hooper, M. (2016). TIMSS 2015 international results in science. Boston College, TIMSS \& PIRLS International Study Center. Retrieved date: Oct. 11, 2019 from http://timssandpirls.bc.edu/timss2015/international-results/

Otsuji, H., Oh, P. S., Lin, C. C., Mui, W. S. W., \& Lu, Y.-L. (2016). Primary school science teacher training in East-Asia: In the continuous reforming for the quality assurance. In H. S. Lin, J. K. Gilbert, \& C. J. Lien (Eds.), Science education research and practice in East Asia: trends and perspectives (pp. 245-272). Taipei: Higher Education Publishing Co., Ltd.

Rivkin, S. G., Hanushek, E. A., \& Kain, J. F. (2005). Teachers, schools, and academic achievement. Econometrica: Journal of Econometric Society, 73(2), 417-458.

Rockoff, J. E. (2004). The impact of individual teachers on student achievement: Evidence from panel data. American Economic Review, 94(2), 247-252.

Teacher Education Act (師資培育法, amended Date 2017-06-14). Laws and Regulations Database of the Republic of China.

Teachers' Act (amended date of 2014-06-18). category (Ministry of Education). Laws and Regulations Database of the Republic of China.

Tuan, H. L., Wang, K. H., \& Chang, H. P. (2016). Taiwanese science teacher education research-capturing the spirit of PCK. In M. H. Chiu (Ed.), Science education research and practices in Taiwan (pp. 309-330). Singapore: Springer.

Wang, H. H., \& Huang, C. C. (2016). Those who can, teach: the academic quality of preservice students in teacher education programmes in Taiwan. Asia-Pacific Journal of Teacher Education, 44(1), 66-79.

Wang, J. R. (2006). Elementary school science and mathematics teachers' professional standards and development study. National Science Council Research Report (NSC-93-2522-S-153-001, NSC-94-2522-S-153-001, NSC-95-2522-S-153-001). Pingtung County: National Pingtung University Chemistry Department.

Wikipedia contributors (2019) "Taiwan." Wikipedia, the Free Encyclopedia last modified last edited on 12 October 2019, Retrieved Oct. 12, 2019 from https://en.wikipedia.org/wiki/Taiwan

\section{Publisher's Note}

Springer Nature remains neutral with regard to jurisdictional claims in published maps and institutional affiliations.

\section{Submit your manuscript to a SpringerOpen ${ }^{\circ}$ journal and benefit from:}

- Convenient online submission

- Rigorous peer review

- Open access: articles freely available online

- High visibility within the field

- Retaining the copyright to your article

Submit your next manuscript at $\boldsymbol{\nabla}$ springeropen.com 